\title{
Chapter 3: The Economic Characterization of Asopos River Basin
}

${ }^{1}$ Koundouri, P., ${ }^{2}$ Papandreou, N. ${ }^{1}$ Stithou, M., ${ }^{3}$ Mousoulides, A., ' Anastasiou, Y., ' Mousoulidou, M., ' Antypas, A., ${ }^{1}$ Souliotis, I. ${ }^{1}$ Mavrogiorgis, T., ${ }^{1}$ Vasiliou, K.

${ }^{1}$ Athens University of Economics and Business, GREECE

${ }^{2}$ Andreas G. Papandreou Foundation, GREECE

${ }^{3}$ Athens University of Economics and Business, GREECE and Intercollege Larnaca, CYPRUS

This chapter puts the emphasis on the economic characterisation of Asopos River Basin (RB) in order to identify the members of the society that will bear the cost of improvements and will benefit from its implementation. Following the first step of Directive's implementation, requiring the economic characterisation of the river basin, there is the need to evaluate the economic significance of water in the region, identify key economic drivers influencing pressures and water uses, examine how these economic drivers will evolve over time and will influence pressures and how will water demand and supply evolve over time. Hence, an important objective of this chapter is to identify the economic significance of water uses, focusing on Asopos experience, considering primarily industrial and agricultural uses since residential and tourist related uses are the focus of Chapter 4.

\section{Introduction}

The first step in the implementation of the Water Framework Directive (WFD) (CEC, 2000) is the economic characterization of water in the region. A comprehensive economic characterization of the water in the region requires first of all that the economic significance of water in the region is evaluated. This involves an assessment of the industrial, agricultural, residential and tourism water needs in the area. However, as the focus of the chapter is the two 
first sectors, analysis will include information for example on the number of industrial units, the industrial water consumption, the total cropped area, cropping patterns, gross production and income of the farming population.

As the first step of the application of the economic characterization includes the economic evaluation of water use in the RB, the evaluation of the economic importance of water use in the area is realized for each sector of the economic activity in order to define the sectors that put more pressure in water use (second step). Every sector of economic activity (primary, secondary, tertiary and households) has a different water use. As a result, for the agriculturallivestock sector water use concerns the irrigation of groundwater or surface water for purposes such as the cultivation of land or to rearing of livestock. For the industrial- artisanship sector, water use takes place for washing and coloring (textiles), steel production, cement production, oil processing, energy production etc. Regarding the tourism sector of economy and domestic sector (households) water use concerns the water supply for home use by the authorized supplier. Water use in Asopos RB is relatively prioritized as follows:

i. Water supply of households, touristic units and holiday home

ii. Irrigation of cultivated areas and livestock units

iii. Industrial water use

In this context, the key economic drivers influencing pressures and water uses need to be determined including (a) the general socio-economic indicators such as population growth, income, and employment; (b) the key sector policies that significantly influence water use (e.g., 
agricultural and environmental policies); (c) the development of planned investments likely to affect water availability; and (d) the implementation of future policies (environmental and other) that is likely to affect water use. These economic drivers will need to be accounted in a dynamic perspective, i.e., to determine how these are likely to evolve over time.

The final component of the economic characterization of water in a region is the application of appropriate methodologies to assess sector-specific water demand. This involves deriving the marginal value of water in consumption and production, the price and income elasticity of demand, the marginal and average willingness to pay for public goods and quality changes of common access resources, and the associated risk parameters.

An overview of land use in Asopos RB is presented in Figure 1 with the beige and light purple colors to represent agricultural and industrial use respectively. The use of specific indexes related to the above sectors of economic activity provides an indication of the economic importance of water use. Depending on the economic activity and consequently on the study area (industrial, touristic, residential, agricultural) the factors and indexes differ. 


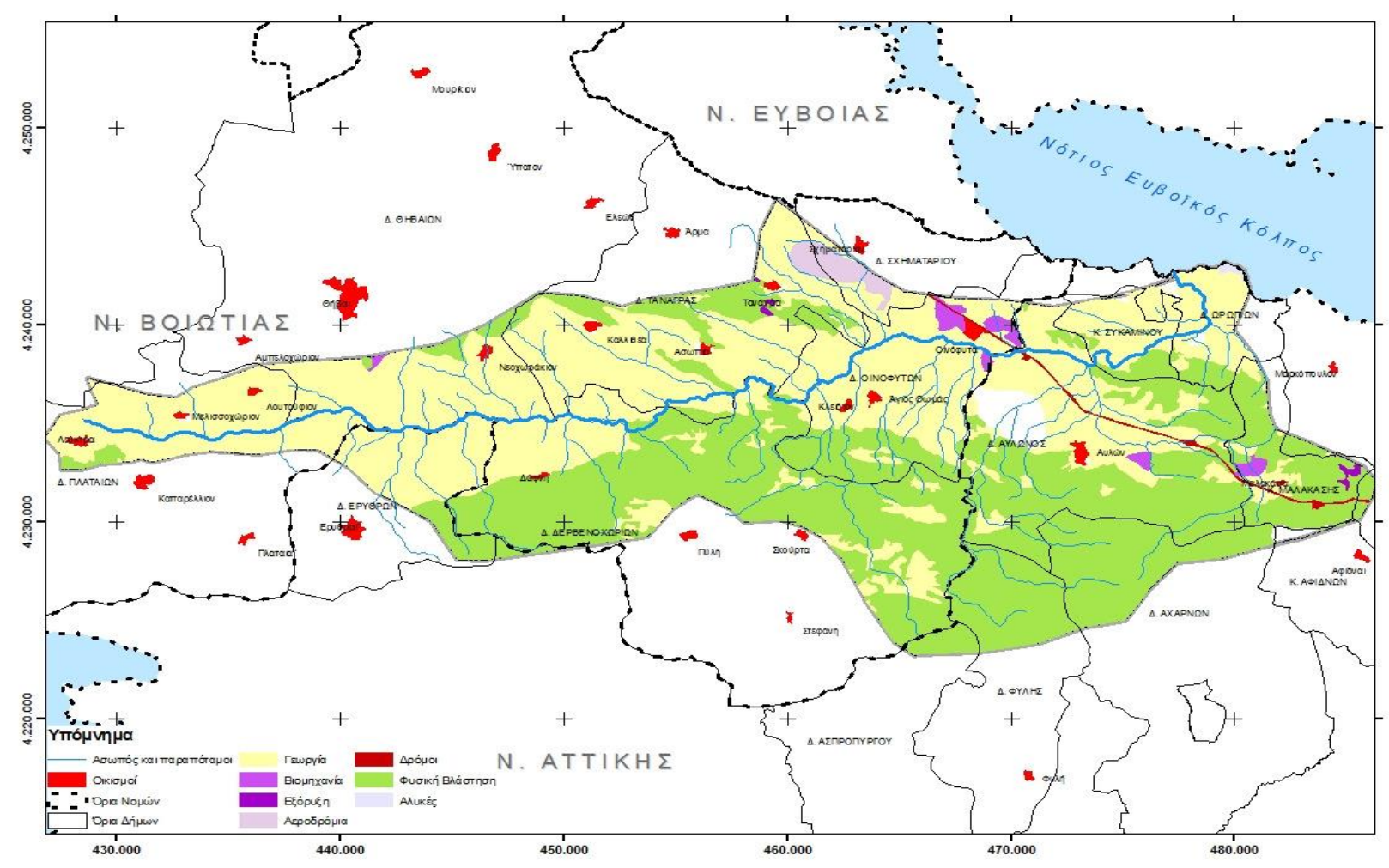

Figure 1: Land use in Asopos RB. (Source: Apostolopoulos, 2010)

The parameters that are selected in order to be used as indexes of evaluation of the economic importance of water use are presented in the following sections.

\section{Industrial area of Asopos River Basin ${ }^{1}$}

The indexes that could be used to evaluate the economic importance of water supply in the industrial area of Asopos are the following:

i. The number of industrial units per sector

ii. Employment

\footnotetext{
${ }^{1}$ Apostolopoulos (2010)
} 
iii. Total number of consumables

iv. Added value

v. Authorities and method of water supplying services

vi. Water pricing followed by water suppliers

vii. Water consumption

\section{i. The number of industrial units per sector}

The index describing the number of industrial units per sector in Table 1 provides information about the way the industrial sector is formed in the case study area. As a result, table shows that the most important sector is that of metallurgy related industries and then the sector of food industries, the sector of plastic products and the sector of textile/dyeing/finishing.

Table 1: Number of industrial units per sector in Asopos RB

\begin{tabular}{ll}
\hline Sector & Number of industrial units \\
\hline Textile/dyeing/finishing & 17 \\
Metallurgy related industries & 51 \\
Food industries & 21 \\
Industries of detergents and cleaning & 6 \\
Industries of production of chemical & 10 \\
Industries of agricultural medicines and & 3 \\
Dyeing industries & 6 \\
Pharmaceutical industries & 4 \\
Industries of plastic products & 21 \\
Industries of animal feed & 3 \\
Other industries & 66 \\
Chicken-livestock establishments & 16 \\
Total & 224 \\
\hline Source : Technical Chamber of Greece (2009)
\end{tabular}

ii. Employment 
Employment can be used for the estimation of the economic activity and the definition of the main sectors of the economy in the area. For that purpose Tables 2 and 3 report data on total employment as well as data on employment per industrial sector. According to the National Statistical Service of Greece ${ }^{2}$ economically active are those who are employed and unemployed. The employed are classified as: (1) individuals of 10 years old and over who the week before the census worked even if that was for an hour and get paid or worked to help their family and (ii) individuals who have a job but the week before the census did not work due to illness, taking days off, because of a strike, weather conditions or for other reasons of temporal natural. Unemployed are those of 10 years old and over who stated that they are actively looking for a job. They are classified between: (1) individuals who lost their job for any kind of reason, and (2) young individuals who were looking for a job for a first time. Considering this terminology and the data reported in Table 3, the total economically active population (labor force) of Asopos RB was 18243 in 2001. Regarding 2001 census data 16725 are employed (91.7\% of the labor force) and 1518 are unemployed ( $8.3 \%$ of the labor force). It is worth noting that for the whole country the respective rate of unemployment was $9.1 \%$ in September 2009 while for the Prefecture of Sterea Ellada it was 9.7\%. The secondary sector is proved to be very important for Asopos RB since $32.9 \%$ of the population is occupied in this sector. Furthermore, considering the fact that the total number of employed in the secondary sector in the Prefecture of Viotia is 13506 (according to 2001 census), the 25\% of these are employed in Asopos RB demonstrating therefore a high industrial concentration in the area.

\footnotetext{
${ }^{2}$ www.statistics.gr
} 
Table 2: Economically active and inactive population in Asopos RB

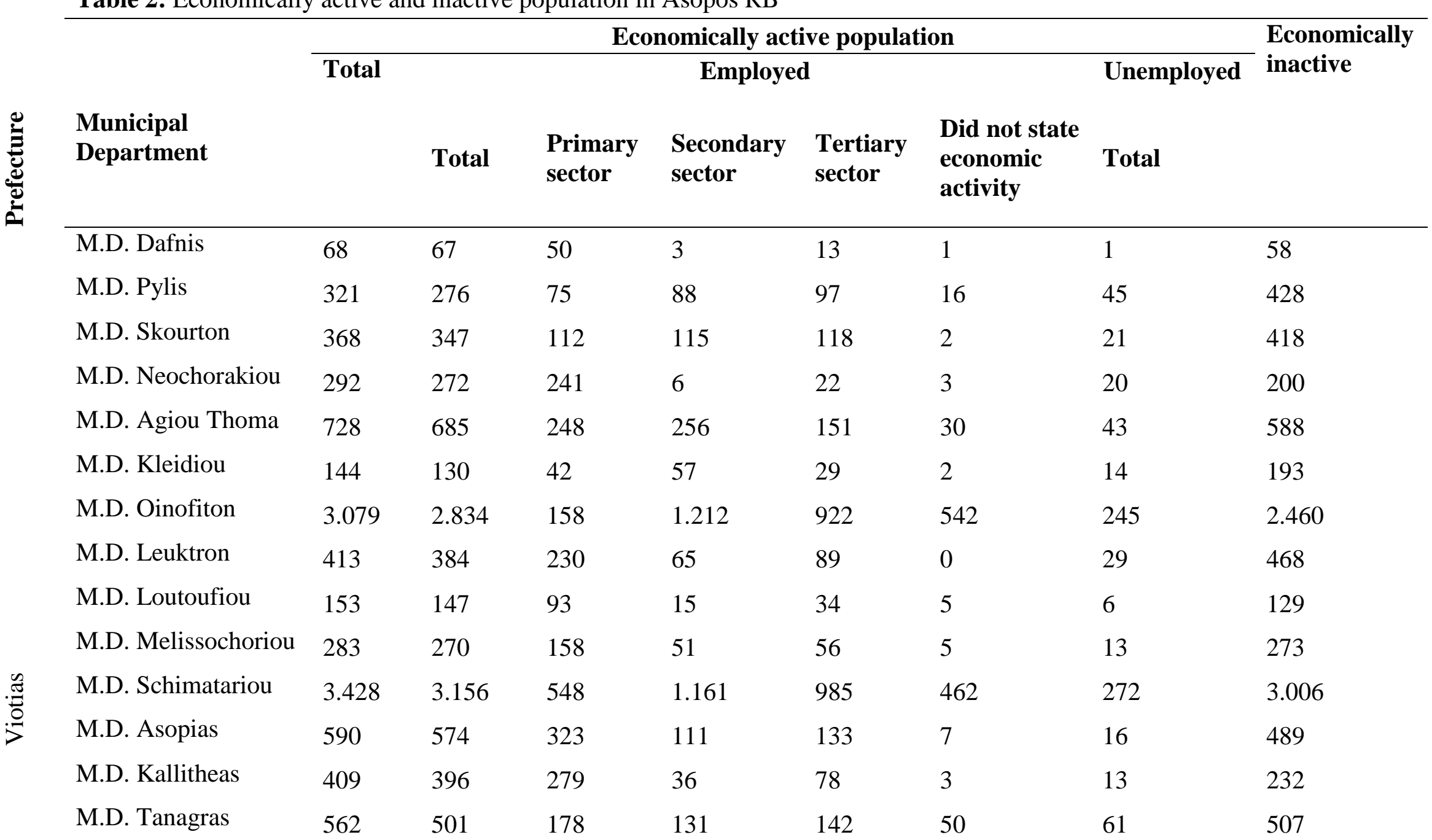




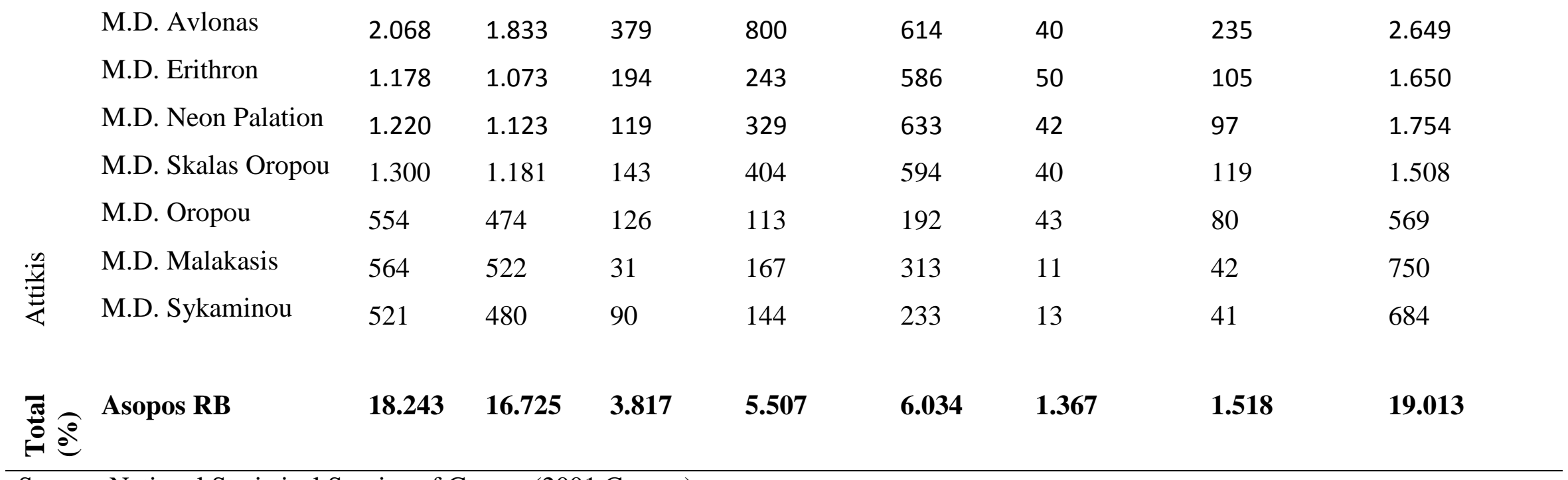

Source: National Statistical Service of Greece (2001 Census) 
In order to analyze further the industrial activity, data per sector are reported in Table 3 . The lowest level of analysis offered by the National Statistical Service of Greece is the Prefecture, however considering the concentration of the industrial activity in Asopos RB the main conclusions that are drawn by observing Viotia Prefecture can be considered to represent satisfactorily the case study area. On the other hand, regarding Prefecture of Attiki the industrial activity within the study site area is only a small percentage of the total Prefecture. Particularly, employment in the secondary sector in the Asopos RB within Attiki Prefecture is the $0.6 \%$ of the Prefecture. Table 3 shows that the sectors of Basic metals and Other transport equipment play the most important role in terms of employment not only for the area but for the whole country. Also important, although demonstrating a less percentage of employment, are the sectors of Food and Drinks, Products of rubber and plastic materials, Metallic products excluding machinery and Products of non metallic minerals. Finally, it is noted that the sector of Electric machines and appliances is of considerable importance in relation to the corresponding employment in the whole country.

Table 3: Employees per sector in the Prefecture of Viotia

\begin{tabular}{llll}
\hline Sector & $\begin{array}{l}\text { Employees in the } \\
\text { Prefecture of } \\
\text { Viotia }\end{array}$ & $\begin{array}{l}\text { Employees in } \\
\text { the whole } \\
\text { country }\end{array}$ & Percentage \\
\hline Food and Drinks & 1741 & 50935 & $3.42 \%$ \\
Tobacco & 0 & 1211 & $0.00 \%$ \\
Textile materials & 582 & 10971 & $5.30 \%$ \\
Leather and leather products & 0 & 2446 & $0.00 \%$ \\
Woodwork and cork & 0 & 2192 & $0.00 \%$ \\
Pulp and paper & 278 & 5332 & $5.21 \%$ \\
Publishing and printing & 0 & 13371 & $0.00 \%$ \\
Chemical products & 888 & 14664 & $6.06 \%$ \\
Products of rubber and plastic & 1698 & 8460 & $20.07 \%$ \\
Products of non metallic minerals & 1078 & 16012 & $6.73 \%$ \\
Basic metals & 3126 & 9865 & $31.69 \%$
\end{tabular}




\begin{tabular}{llll} 
Metallic products excluding machinery & 1291 & 12843 & $10.05 \%$ \\
Machinery and equipment & 308 & 10124 & $3.04 \%$ \\
Electric machines and appliances & 517 & 3525 & $14.67 \%$ \\
Other transport equipment & 3039 & 10713 & $28.37 \%$ \\
Furniture and other industries & 184 & 2393 & $7.69 \%$ \\
Total & 14730 & 175057 & $8.4 \%$ \\
\hline
\end{tabular}

Source : National Statistical Service of Greece (personal contact)

\section{iii. Total number of consumables}

According to the National Statistical Service of Greece the terminology "Total number of consumables" include the value of first and aid materials, the value of packing consumable material, of fuels, of electric power and the rest of consumable materials during the specific year. This index can be used for the estimation of the contribution of each industrial sector to the other economic activities from which its inflows result from.

Table 4 shows that of particular importance are the sectors of Basic metals and Electric machines and appliances not only for the study site area but also for the whole country. Furthermore, within Asopos RB the sector of Food and drinks is quite important while considering the whole country the sectors of Other transport equipment, Products of rubber and plastic materials and Metallic products excluding machinery have a considerable contribution.

Table 4: Total consumables per sector in the Prefecture of Viotia

\begin{tabular}{llll}
\hline Sector & $\begin{array}{l}\text { Total } \\
\text { consumables in } \\
\text { the Prefecture } \\
\text { of Viotia }\end{array}$ & $\begin{array}{l}\text { Total } \\
\text { consumables } \\
\text { in the whole } \\
\text { country }\end{array}$ & Percentage \\
\hline Food and Drinks & 393248050 & 4205316543 & $9.35 \%$ \\
Tobacco & 0 & 93664815 & $0.00 \%$ \\
Textile materials & 28758237 & 578699431 & $4.97 \%$ \\
Leather and leather products & 0 & 78967760 & $0.00 \%$
\end{tabular}




\begin{tabular}{llll} 
Woodwork and cork & 0 & 119584404 & $0.00 \%$ \\
Pulp and paper & 15107816 & 399564692 & $3.78 \%$ \\
Publishing and printing & 0 & 560127151 & $0.00 \%$ \\
Chemical products & 62815814 & 1464315634 & $4.29 \%$ \\
Products of rubber and plastic & 136605144 & 639968089 & $21.35 \%$ \\
Products of non metallic minerals & 129432576 & 1560346128 & $8.30 \%$ \\
Basic metals & 1588879071 & 3335063768 & $47.64 \%$ \\
Metallic products excluding machinery & 113760436 & 987946274 & $11.51 \%$ \\
Machinery and equipment & 25034560 & 551207972 & $4.54 \%$ \\
Electric machines and appliances & 239936678 & 392671818 & $61.10 \%$ \\
Other transport equipment & 79771718 & 289636135 & $27.54 \%$ \\
Furniture and other industries & 5412537 & 81478565 & $6.64 \%$ \\
Total & 2381648534 & 15338559179 & $15.53 \%$ \\
\hline Source: Nation Statictical Service
\end{tabular}

Source : National Statistical Service of Greece (personal contact)

iv. Added value

According to the National Statistical Service of Greece Added value is defined as the difference between the value of the produced products during a specific period of time, the revenues from service providing to third parties and any other revenues and the total of consumables. This index can be used to estimate the importance of each industrial sector in producing income and in the economic growth. Table 5 shows that the most important sectors for the study site and whole country regarding income production are the sector of Basic metals and the sector of Electric machines and appliances. Of special importance within the study site is the sector of Food and drinks, while compared to the whole of the country the sectors of Other transport equipment and Products of rubber and plastic materials are quite important.

Table 5: Added value per sector in the Prefecture of Viotia

\begin{tabular}{llll}
\hline Sector & $\begin{array}{l}\text { Added value in } \\
\text { the Prefecture } \\
\text { of Viotia }\end{array}$ & $\begin{array}{l}\text { Added value in } \\
\text { the whole } \\
\text { country }\end{array}$ & Percentage \\
\hline Food and Drinks & 254197230 & 3076272044 & $8.00 \%$
\end{tabular}




\begin{tabular}{llll} 
Tobacco & 0 & 158920035 & $0.00 \%$ \\
Textile materials & 14694267 & 367556710 & $4.00 \%$ \\
Leather and leather products & 0 & 75011709 & $0.00 \%$ \\
Woodwork and cork & 0 & 58908378 & $0.00 \%$ \\
Pulp and paper & 10167978 & 255273253 & $3.98 \%$ \\
Publishing and printing & 0 & 732108592 & $0.00 \%$ \\
Chemical products & 50508496 & 948708901 & $5.32 \%$ \\
Products of rubber and plastic & 78652072 & 390838151 & $20.12 \%$ \\
Products of non metallic minerals & 125734697 & 1233588438 & $10.19 \%$ \\
Basic metals & 339459178 & 1042092592 & $32.57 \%$ \\
Metallic products excluding machinery & 65606262 & 633186191 & $10.36 \%$ \\
Machinery and equipment & 13484094 & 380555411 & $3.54 \%$ \\
Electric machines and appliances & 61073554 & 153838838 & $39.70 \%$ \\
Other transport equipment & 139255582 & 581846913 & $23.93 \%$ \\
Furniture and other industries & 8583994 & 77267486 & $11.11 \%$ \\
Total & 1161417404 & 10165973642 & $11.42 \%$ \\
\hline Source: Nationa
\end{tabular}

Source : National Statistical Service of Greece (personal contact)

\section{v. Competent bodies and method of water supplying services}

The water supply and sewage services are considered in the case of Greece as a public service. Across the country there are 214 enterprises for water supply and sewerage. The relevant competent bodies fall into three categories (Safarikas et al., 2006; Tsagarakis et al., 2003):

(i) In Athens and Thessaloniki cities - owned companies (non profit making corporations) own and operate the treatment plants (for water supply and wastewater) but function as private enterprises with a 20-year concession contract. In Athens, the Company for Water Supply and Sewerage of the Capital (EYDAP) and in Thessaloniki, the Company for Water Supply and Sewerage of Thessaloniki (EYATH). They are inspected by the Ministry of Environment, Planning, and Public Works (MoEPPW) that approves the pricing policy. The EYDAP S.A and EYATH S.A both serve the 53\% of the total Greek population. EYDAP S.A was established by the Law 1068/80 and the Greek State was 
shareholder, while EYATH S.A was established based on the Law 2651/1998 and the only shareholder was the Greek State. The first provides waters services to about 4.000.000 residents having 1.831 .520 connections and $8.078 \mathrm{~km}$ of water supply network and sewage services to about 3.300 .000 residents having a $5.800 \mathrm{~km}$ network of sewerage. The former serves 1.700 .000 residents supplying $250.000 \mathrm{~m}^{3}$ per day using a $1.800 \mathrm{~km}$ of water supply network and 1.450 .000 residents supplying $170.000 \mathrm{~m}^{3}$ per day using a $1.600 \mathrm{~km}$ network of sewerage. The networks account for $45 \%$ of the volume supplied while the population served by EYDAP and EYATH is estimated to be 53\% of the total population of Greece.

(ii) Cities with more than 10,000 inhabitants are managed by Municipal Enterprises for Water Supply and Sewerage (DEYA) operating as private companies, but owned by the municipalities (Law 1069/80). However, there are also cities with population less than 10,000 inhabitants in which DEYA have been established. There are about 210 DEYA around the country from which 177 are organized and represented by the Union of Municipal Enterprises for Water Supply and Sewerage and provide their services to 3.500.000 residents. In total the DEYAs of the country serve the $35 \%$ of the population through 1.300.000 connections for water supply. The area of DEYA's jurisdiction is defined as the area of the corresponding Municipality. According to the Law 2539/97 "Ioannis Kapodistrias" new Municipalities were created having a population of more than 10.000 residents resulting to the obligation of establishing a DEYA, since according to the Law 1069/80, a Municipality with population of over 10.000 residents that doesn't create DEYA is not entitled to be subsidized by the Public Investment Program (DEYA 65\% and Program 35\%). This is the reason that the number of DEYA was double from 
105 in 1997 to 210. DEYA have as an objective the water supply and sewerage services provision while being responsible for the water quality, the early response to water shortage, the maintenance of the water supply and sewerage network, the construction of water supply projects etc. Population served by DEYA is estimated to be $35 \%$ of the total population of Greece.

(iii) In the rest of the areas (towns/municipalities with less than 10.000 residents) the competent bodies are the Municipalities. These Municipalities which are responsible directly for water supply and wastewater services are about 830 and account for only $12 \%$ of the total population served.

Focusing in the area of Asopos RB the above three independent systems are met as well as combination of these.

\section{vi. Water pricing followed by water suppliers}

Pricing of water consumption is a very important since it defines the credibility and the quality of water supply as well as the possibility of developing new programs for the satisfaction of future, quantitative and qualitative needs. According to the national program of management and protection of water resources that was planned by the Ministry of Environment Physical Planning and Public Works (MoEPPW), it is foreseen the definition of the water price, for all uses, through the relationship of cost-benefit. According to Article 9 of WFD (Article 8 P.D.51/2007), water pricing should have been applied till the end of 2010 so as: 
- To provide the necessary incentives to the users in order to use effectively water resources and consequently to contribute to the achievement of the relevant environmental targets (Article 4 P.D. 51/07) and

- To establish the contribution of water use (industrial, irrigation and water supply) to recover the cost of water services, according to the principle of "polluter pays" and the economic analysis as described in the Annex IV of P.D. 51/07.

As a result, water pricing can contribute to the achievement of two particular objectives:

- The adoption of a plan for a sustainable environmental economy by reducing excessive consumption and optimizing the use of natural resources so to assure a satisfactory level of life.

- The establishment of a homogeneous way of gathering and processing necessary data for the expense accounting of water use.

As commented also in Chapter 1 through water pricing it should be aimed to:

- The recovery of financial cost (Capital Cost, Operation Cost, Maintenance Cost, Administrative Cost and Cost of Agricultural Subsidies) through the fees/payments for water supply and sewerage,

- The charge for excessive consumption which is to treated as pollution,

- The recovery of the environmental cost (associated with the impact on environment and social welfare as a result of the reduction in environmental quality),

- The assurance of regular water supply for the financially sensitive social groups and

- The recovery of the cost of natural resources (which is related to the reduction of the available quantity of the resource due to overexploitation). 
Every system of providing services of water supply and sewerage such as EYDAP S.A, EYATH S.A, DEYA and Municipalities, follow a different water pricing policy since they differ in terms of operation and financial data which are to be considered in the pricing of water supply.

In particular, EYDAP S.A and EYATH S.A as privatized state owned and nongovernmental companies set the prices which should however be approved by the state and cover their cost of operation. The pricing that EYDAP S.A employs defines ten categories of water use and users and imposes successive/escalating or standard charge and a monthly fixed charge depending on three months consumption.

According to EYDAP S.A billing for the industry:

- It is foreseen a compulsory consumption of $100 \mathrm{~m}^{3} / \mathrm{month}$

- For consumption up to $1000 \mathrm{~m}^{3}$ the charge is $0,8381 € / \mathrm{m}^{3}$

- For consumption over $1000 \mathrm{~m}^{3}$ the charge is $0,9866 € / \mathrm{m}^{3}$

- A monthly fixed fee ranging from $4,37 €$ to $43,62 €$ depending on the diameter of the water metering appliance

In addition, the billing system of EYDAP S.A has four categories of users regarding sewer use who are charged as a percentage of water price. In particular, as far as industry is concerned the right of use of sewage system is defined at $75 \%$ of the value of consumed water excluding the sectors of beverages, ice-factories, paper-factories, and the industries of artificial silk for which the percentage reaches the $35 \%$ of the value of the consumed water. Finally, pricing includes charges as V.A.T of $9 \%$ of the value of consumed water and $19 \%$ for the rest of uses as well as a 
charge of $1 \%$ of the consumed water as a contribution to the fund responsible for the personnel's insurance.

Every DEYA which operates as a private company sets the prices which have to be approved from the City Council and cover the operational cost. Hence, for the calculation of the operational cost and the implementation of water pricing the following factors are considered:

- Expenses and salaries related to the personnel,

- Expenses and salaries related to third parties,

- Subsidies of third parties,

- Taxes-duties,

- Other expenses,

- Rates of interest and related expenses,

- Depreciation of capital etc

However, WFD changes completely the way of operation of DEYA, and in particular their water pricing policy through the need for full cost recovery of water supply and sewerage. As a result, DEYA's water pricing policy should count in, apart from the financial cost, the cost of natural resources and the environmental cost.

Considering that the main size of the industrial activity is located in the Municipalities of Oinofiton and Schimatariou the following table (Table 6) presents the water pricing policy that is followed for industrial uses in these particular Municipalities. 
Table 6: Water pricing for industrial use in the Municipalities of Oinofiton and Schimatariou

\begin{tabular}{lllll}
\hline Municipality & Frequency of bill & Fixed fee $(€)$ & Pricing & Amount $\left(€ / \mathrm{m}^{3}\right)$ \\
\hline Schimatariou & 3 months & 85,28 & Until $30 \mathrm{~m}^{3}$ & 1,70 \\
& & & $31 \mathrm{~m}^{3}-90 \mathrm{~m}^{3}$ & 1,84 \\
& & $91 \mathrm{~m}^{3}-180 \mathrm{~m}^{3}$ & 2,30 \\
& & $181 \mathrm{~m}^{3}-270 \mathrm{~m}^{3}$ & 3,05 \\
& & $271 \mathrm{~m}^{3}-360 \mathrm{~m}^{3}$ & 4,58 \\
Oinofiton & \multirow{2}{*}{6 months } & \multirow{2}{*}{14,67} & More than $360 \mathrm{~m}^{3}$ & 6,10 \\
& & Single & 0,59
\end{tabular}

Source: Municipalities of Schimatariou and Oinofiton (personal contact)

It should be noted that many industrial units in the area of Oinofiton - Schimatariou are supplied with water directly from EYDAP S.A. and the corresponding pricing is used.

\section{vii. Water consumption}

This index includes the data of water consumption and the value of water according to the current pricing that the Municipalities apply. In the value of water the fixed fee is not included. The data regarding water consumption are coming from the Municipalities of Oinofiton and Schimatariou since the main size of industrial activity is located in these Municipalities.

Table 7: Water pricing for industrial use in the Municipalities of Oinofiton and Schimatariou

\begin{tabular}{llll}
\hline Municipality & Consumption $\left(\mathrm{m}^{3}\right)$ & Fixed fee $(€)$ & Value of water $(€)$ \\
\hline Schimatariou & 111.711 & 43.374 & 297.320 \\
Oinofiton & 240.788 & 2.963 & 142.065 \\
\hline
\end{tabular}

Source: Municipalities of Schimatariou and Oinofiton (personal contact) 


\section{Agricultural area of Asopos River Basin}

The indexes that could be used for the assessment of the economic significance of water use for the agricultural area of Asopos RB are the following:

\section{i. Agricultural land per crop}

ii. Production per crop

iii. Yields per crop

iv. Irrigated land per crop

v. Subsidies

vi. Investments

Next each one of the indexes is analyzed as well as the way that each one can be used for the description of the agricultural activity in the area.

\section{i. Agricultural land per crop}

This index is consisted of the average land in "stremmata" $\left(1.000 \mathrm{~m}^{2}\right)$ that was used for each crop during the years 2004, 2005 and 2006. This index can be used in order to describe the most important crops in the area.

Table 8: Agricultural land per crop

\begin{tabular}{llll}
\hline Crop category & $\begin{array}{l}\text { Agricultural land in } \\
\text { Asopos RB (str.) }\end{array}$ & $\begin{array}{l}\text { Agricultural land in the } \\
\text { country (str.) }\end{array}$ & $\%$ \\
\hline Cereals for grain & 145.751 & 12.083 .038 & $1,21 \%$ \\
Tree crops & 54.461 & 9.681 .422 & $0,56 \%$
\end{tabular}




$\begin{array}{llll}\text { Industrial plants } & 24.482 & 3.744 .148 & 0,65 \% \\ \text { Vineyards } & 23.311 & 817.967 & 2,85 \% \\ \text { Vegetables } & 18.894 & 989.177 & 1,91 \% \\ \text { Fodder plants } & 17.370 & 3.088 .495 & 0,56 \% \\ \text { Potatoes } & 6.972 & 479.970 & 1,45 \% \\ \text { Melons/watermelo } & 6.097 & 259.804 & 2,35 \% \\ \text { ns } & & & \\ \text { Edible pulses } & 2.475 & 140.114 & 1,77 \% \\ \text { Total } & 299.814 & 31.284 .133 & 0,96 \%\end{array}$

Source: National Statistical Service of Greece, Annual Agricultural Statistical Survey 2004, 2005 and $2006^{3}$

From the above table it is observed that cereals occupy the biggest part of the agricultural land in the study area (about $50 \%$ of the total area) and specifically the hard wheat which was cultivated on average in 132.400 str. The tree crops follow (18\% of the total land) and specifically the olive trees for olive oil production which occupy on average 53.670 str. Industrial plants represent only the $8 \%$ of the total land the same as vineyards while the vegetables the $6 \%$ the same as forage. In total the main crops (hard wheat, olive trees, cotton, vineyards and dry onions) sum up to $80 \%$ of the total agricultural land in the study site.

\section{ii. $\quad$ Production per crop category}

This index consists of the average yield in kilos (kgr) that was produced for each crop during 2004, 2005 and 2006. This index can be used in order to describe the most important crops that can be found in the area.

\footnotetext{
${ }^{3}$ http://www.statistics.gr/portal/page/portal/ESYE/PAGE-themes?p_param=A0403
} 
Table 9: Production per crop category

\begin{tabular}{|c|c|c|c|}
\hline Crop category & $\begin{array}{l}\text { Production in Asopos } \\
\text { RB (kgr) }\end{array}$ & $\begin{array}{l}\text { Production in the } \\
\text { country (kgr) }\end{array}$ & $\%$ \\
\hline Vegetables & 71.887 .800 & 2.941 .680 .656 & $2,44 \%$ \\
\hline $\begin{array}{l}\text { Cereals for } \\
\text { grain }\end{array}$ & 31.298 .950 & 4.767 .737 .027 & $0,66 \%$ \\
\hline Vineyards & 25.559 .133 & 807.575 .239 & $3,16 \%$ \\
\hline Potatoes & 16.605 .333 & 965.423 .636 & $1,72 \%$ \\
\hline $\begin{array}{l}\text { Melons/waterm } \\
\text { elons }\end{array}$ & 16.477 .153 & 870.490 .654 & $1,89 \%$ \\
\hline Tree crops & 6.602 .773 & 4.883 .725 .651 & $0,14 \%$ \\
\hline Industrial plants & 6.262 .383 & 1.182 .360 .583 & $0,53 \%$ \\
\hline Fodder plants & 4.971 .583 & 2.044 .026 .573 & $0,24 \%$ \\
\hline Edible pulses & 425.250 & 30.454 .670 & $1,40 \%$ \\
\hline Total & 180.090 .359 & 18.493 .474 .689 & $0.97 \%$ \\
\hline
\end{tabular}

From the above table (Table 9) it is observed that vegetables are the $40 \%$ of the total production and especially the dry onions which reported a three year production of $36.658 .000 \mathrm{kgr}$. Cereals for grain follow (17\% of the total area) and particularly the hard wheat with $28.567 .817 \mathrm{kgr}$ of production and then the vineyards (14\% of the production). Of less importance is the potatoes production and melons/watermelons (about 9\% each) and of even less the tree crops, the industrial plants and the fodder plants. In total the main categories of crops (hard wheat, vineyards, dry onions, potatoes and melons/watermelons) sum up to about $70 \%$ of the production in the study site.

\footnotetext{
${ }^{4}$ Op.cit. 3
} 


\section{iii. $\quad$ Yields per crop category}

This yield consists of the average yield per stremma $\left(\mathrm{kgr} / 1.000 \mathrm{~m}^{2}\right)$ for each of the main crops (hard wheat, irrigated cotton, non-irrigated cotton, olive trees) during 2004, 2005 and 2006. This index compared to the corresponding prices for the total of the non-mountainous areas of the country, can be used to describe the quality of the soil and climate conditions of the area but also the intense of the agricultural practices. The choice of the non-mountainous areas is made for comparison reasons since the area of Asopos RB does not include mountainous regions as these are defined in the Directive $85 / 148 / \mathrm{EE}^{5}$

Table 10: Production per crop category

\begin{tabular}{llll}
\hline Crop category & $\begin{array}{l}\text { Yield in Asopos RB } \\
(\mathrm{kg} / \mathrm{str})\end{array}$ & $\begin{array}{l}\text { Yield of non- } \\
\text { mountainous areas of } \\
\text { the country (kg/str) }\end{array}$ & \\
Hard wheat & 216 & 244 & $88 \%$ \\
Non-irrigated cotton & 124 & 187 & $66 \%$ \\
Irrigated cotton & 338 & 321 & $105 \%$ \\
Dry onions & 5.356 & 3.284 & $163 \%$ \\
Olive trees & 111 & 377 & $29 \%$ \\
Vineyards, mainly for & 1.095 & 1.011 & $108 \%$ \\
wine production & & & $105 \%$ \\
Vineyards, mainly for & 1.844 & 1.759 & \\
table grapes & & &
\end{tabular}

Source: National Statistical Service of Greece, Annual Agricultural Statistical Survey 2004, 2005 and $2006^{6}$

\footnotetext{
${ }^{5}$ EE L 56 of 25.2.1985, p. 1 to 59

${ }^{6}$ Op.cit. 3
} 
From the above table it is concluded that the hard wheat, the vineyards and the irrigated cotton are comparable to the rest of the country, while non-irrigated cotton and mainly the olive trees fall short considerably. On the other hand, the dry onions present an increased yield in Asopos RB.

\section{iv. $\quad$ Irrigated land per crop}

This index includes the average irrigated land during the three years period 2004-2006 per crop category. It can be used for the estimation of the real needs in the area as far as irrigation is concerned. In addition, considering that the average price for water consumption for irrigation is $€ 13.73$ per stremma of irrigated land (Koundouri et al., 2009) it is possible to calculate the value of water for irrigation.

Observing the following table (Table 10) and considering the land per crop category, it is noticed that from about 203.000 str. which include plants of long-living plantations and other crops (cereals for grain, pulses, industrial plants, fodder plants, melons/watermelons and potatoes) only 28.444 str. were irrigated. From this area the higher percentage belongs to the irrigated cotton which occupies an area of about 15.000 str. The value of water for irrigation is estimated at $€ 755.850$.

Table 11: Irrigated land per crop category

\begin{tabular}{lll}
\hline Crop category & Irrigated land $($ str $)$ & Cost of use $(€)$ \\
\hline Plants of long-living & 28.444 & 390.536 \\
plantations & &
\end{tabular}




$\begin{array}{lll}\text { Vegetables } & 18.894 & 259.415 \\ \text { Tree plants } & 6.004 & 82.435 \\ \text { Vineyards } & 1.709 & 23.465 \\ \text { Total } & 55.051 & 755.850\end{array}$

Source: National Statistical Service of Greece, Annual Agricultural Statistical Survey 2004,2005 and $2006^{7}$

\section{v. Subsidies}

The subsidies that are provided to the produces in the framework of the first pillar of the Common Agricultural Policy are regarded that increase the cost of the resources. The resource cost in case of water represents the opportunity cost of water use compared to other present or future uses, which are excluded due to the current use of the resource beyond its degree of natural replenishment or recovery (European Communities 2002-WATECO). According to this definition subsidies could be considered that create an incentive for water use excluding it from current or future uses. For the right estimation of the cost of the resource it should be taken under consideration only that part of subsidies that can be correlated with water use. For that purpose water elasticity prices are considered in the production function of each crop category, which is estimated at 0,1 for cereals and pulses, 0,36 for industrial plants and 0,2 for olives (Koundouri et al., 2009). According to these prices and the total height of the subsidies the percentage of subsidies that corresponds to each water use can be calculated.

In the next table (Table 12) the total subsidies per Municipal Department in Asopos RB are presented as published by the Greek Payment Authority ${ }^{8}$ of Common Agricultural Policy (CAP)

\footnotetext{
${ }^{7}$ Op.cit. 3
} 
Aid Schemes for 2008. Considering the fact that there is no division of the subsidies per crop category, the percentage of land that each crop occupies in each Municipal Department could be used so as to part the subsidies per crop category. For that purpose in Table 13 it is presented the percentage of land that each of the main crop categories occupies per Municipal Department in Asopos RB.

Table 12 : Subsidies of the European Agricultural Guarantee Fund (EAGF) in Asopos RB

\begin{tabular}{|c|c|c|c|}
\hline Prefecture & $\begin{array}{l}\text { Municipality/ } \\
\text { Commune }\end{array}$ & Municipal Department & Direct Payments $(€)$ \\
\hline \multirow{15}{*}{ Viotias } & M. Dervenochorion & M.D. Dafnis & 440.019 \\
\hline & & M.D. Pylis & 557.395 \\
\hline & & M.D. Skourton & 592.804 \\
\hline & M. Thivaion & M.D. Neochorakiou & 696.895 \\
\hline & M. Oinofiton & M.D. Agiou Thoma & 966.363 \\
\hline & & M.D. Kleidiou & 349.450 \\
\hline & & M.D. Oinofiton & 121.402 \\
\hline & M. Plataion & M.D. Leuktron & 789.778 \\
\hline & & M.D. Loutoufiou & 910.677 \\
\hline & & M.D. Melissochoriou & 775.253 \\
\hline & M. Schimatariou & M.D. Schimatariou & 662.739 \\
\hline & M. Tanagras & M.D. Asopias & 645.651 \\
\hline & & M.D. Kallitheas & 563.657 \\
\hline & & M.D. Tanagras & 617.985 \\
\hline & M. Avlonos & M.D. Avlonas & 821.005 \\
\hline \multirow{4}{*}{ Attikis } & M. Erithron & M.D. Erithron & 1.855 .814 \\
\hline & M. Oropion & M.D. Neon Palation & 5.632 \\
\hline & & M.D. Skalas Oropou & 25.601 \\
\hline & & M.D. Oropou & 58.946 \\
\hline
\end{tabular}

${ }^{8}$ Payment and Control Agency for Guidance and Guarantee Community Aid (OPEKEPE) 

M. Malakasas
M.D. Malakasis
36.293
M. Sykaminou
M.D. Sykaminou
199.461

Total

11.692 .819

Source: Payment and Control Agency for Guidance and Guarantee Community Aid (OPEKEPE). Data of year 2008. http://www.e-enisxyseis.gr

Table 13: Percentage of agricultural land per crop category in Asopos RB

\begin{tabular}{|c|c|c|c|c|c|}
\hline Prefecture & $\begin{array}{l}\text { Municipality/ } \\
\text { Commune }\end{array}$ & Municipal Department & $\begin{array}{l}\text { Cereals } \\
\& \\
\text { Pulses }\end{array}$ & $\begin{array}{l}\text { Indust } \\
\text { rial } \\
\text { plants }\end{array}$ & $\begin{array}{l}\text { Olive } \\
\text { trees }\end{array}$ \\
\hline \multirow{15}{*}{ Viotias } & M. Dervenochorion & M.D. Dafnis & $92 \%$ & $6 \%$ & $2 \%$ \\
\hline & & M.D. Pylis & $60 \%$ & $3 \%$ & $37 \%$ \\
\hline & & M.D. Skourton & $99 \%$ & $0 \%$ & $1 \%$ \\
\hline & M. Thivaion & M.D. Neochorakiou & $91 \%$ & $9 \%$ & $0 \%$ \\
\hline & M. Oinofiton & M.D. Agiou Thoma & $59 \%$ & $7 \%$ & $34 \%$ \\
\hline & & M.D. Kleidiou & $73 \%$ & $1 \%$ & $26 \%$ \\
\hline & & M.D. Oinofiton & $54 \%$ & $2 \%$ & $44 \%$ \\
\hline & M. Plataion & M.D. Leuktron & $48 \%$ & $15 \%$ & $37 \%$ \\
\hline & & M.D. Loutoufiou & $56 \%$ & $37 \%$ & $6 \%$ \\
\hline & & M.D. Melissochoriou & $48 \%$ & $39 \%$ & $13 \%$ \\
\hline & M. Schimatariou & M.D. Schimatariou & $67 \%$ & $6 \%$ & $26 \%$ \\
\hline & M. Tanagras & M.D. Asopias & $76 \%$ & $0 \%$ & $24 \%$ \\
\hline & & M.D. Kallitheas & $90 \%$ & $8 \%$ & $2 \%$ \\
\hline & & M.D. Tanagras & $42 \%$ & $17 \%$ & $40 \%$ \\
\hline & M. Avlonos & M.D. Avlonas & $66 \%$ & $1 \%$ & $32 \%$ \\
\hline \multirow{3}{*}{ Attikis } & M. Erithron & M.D. Erithron & $74 \%$ & $24 \%$ & $2 \%$ \\
\hline & M. Oropion & M.D. Neon Palation & $33 \%$ & $0 \%$ & $67 \%$ \\
\hline & & M.D. Skalas Oropou & $32 \%$ & $0 \%$ & $68 \%$ \\
\hline
\end{tabular}


M.D. Oropou $\quad 33 \% \quad 0 \% \quad 67 \%$

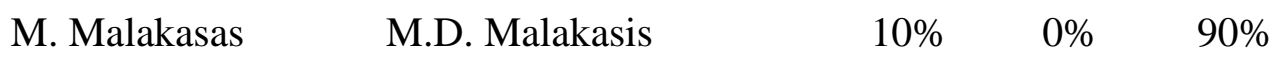

$\begin{array}{llll}\text { M. Sykaminou } & \text { M.D. Sykaminou } & 31 \% & 0 \%\end{array}$

Source: National Statistical Service of Greece, Annual Agricultural Statistical Survey 2004, 2005 and $2006^{9}$

Combining both of the above tables and considering the subsequent elasticities, Table 14 emerges in which the amount of subsidies that corresponds to water use is presented. The total amount reaches $818.799 €$ and is an estimation of the resource cost as a result of its current use in agricultural activities.

Table 14 : Subsidies that correspond to water use in Asopos RB

\begin{tabular}{llll}
\hline Prefecture & $\begin{array}{l}\text { Municipality/ } \\
\text { Commune }\end{array}$ & Municipal Department & $\begin{array}{l}\text { Subsidies that } \\
\text { correspond to water } \\
\text { use (€) }\end{array}$ \\
\hline \multirow{2}{*}{ Viotias } & M. Dervenochorion & M.D. Dafnis & 41.466 \\
& M.D. Pylis & 33.759 \\
M. Oinofiton & M.D. Skourton & 58.940 \\
& M.D. Neochorakiou & 65.456 \\
& M.D. Agiou Thoma & 58.670 \\
& M.D. Kleidiou & 25.617 \\
& M. Plataion & M.D. Oinofiton & 6.567 \\
& M.D. Loutoufiou & 40.186 \\
& M.D. Melissochoriou & 58.158 \\
M. Schimatariou & M.D. Schimatariou & 42.376 \\
M. Tanagras & M.D. Asopias & 45.587 \\
\end{tabular}

${ }^{9}$ Op.cit. 3 


\begin{tabular}{|c|c|c|c|}
\hline & & M.D. Kallitheas & 52.026 \\
\hline & & M.D. Tanagras & 28.012 \\
\hline & M. Avlonos & M.D. Avlonas & 54.684 \\
\hline & M. Erithron & M.D. Erithron & 148.999 \\
\hline & M. Oropion & M.D. Neon Palation & 184 \\
\hline & & M.D. Skalas Oropou & 814 \\
\hline Attikis & & M.D. Oropou & 1.942 \\
\hline & M. Malakasas & M.D. Malakasis & 361 \\
\hline & M. Sykaminou & M.D. Sykaminou & 6.193 \\
\hline
\end{tabular}

Total

818.799

vi. Investments

This index includes the investments that took place in Asopos RB in the context of the "Operational Program for the Agricultural Development and Reform of the Country Side" for the period $2000-2006$. The investments that are reported in the area concern agricultural holdings (plans of improvement) and premium for the setting up in farming of young farmers, while there are no investments in the framework of the Program for agro-industry.

The relevant table (Table 15) shows that the biggest part of the investments in the context of the Program concerns the setting up in farming of young farmers and therefore it is expected an update in the age range of the agricultural population of the area as well as an improvement in the level of specialization of the occupied people in agriculture. This improvement in the human capital can lead to an increase of productivity of the agricultural sector of the area and can have both positive and negative impacts on the environment. The negative impacts can be the result of 
possible increased needs in inputs (fertilizers, water) because of the increase in the production, while the positive impacts can be ought to the higher awareness and specialization of the young farmers in issues of sustainable agriculture.

The investments in natural capital in agricultural holdings is more likely to lead to an increased need for inputs rather than to an reduction of inputs since these investments do not primary concern improvements in the methods of production towards a sustainable direction.

Table 15 : Investments in Asopos River basin due to the "Operational Program for the Agricultural Development and Reform of the Country Side" for the period 2000-2006

\begin{tabular}{lll}
\hline $\begin{array}{l}\text { Municipality/ } \\
\text { Commune }\end{array}$ & $\begin{array}{l}\text { Investments in agricultural } \\
\text { holdings }(\boldsymbol{\epsilon})\end{array}$ & $\begin{array}{l}\text { Single premium for setting } \\
\text { up a new holding }(\boldsymbol{\epsilon})\end{array}$ \\
\hline M. Dervenochorion & 8.252 & 489.400 \\
M. Thivaion & 760.818 & 1.885 .100 \\
M. Oinofiton & 6.490 & 1.163 .700 \\
M. Plataion & 332.110 & 1.883 .100 \\
M. Tanagras & 386.593 & 1.904 .100 \\
Total & 1.494 .262 & 7.325 .400 \\
\hline
\end{tabular}

Source: Monitoring Information System

(http://www.ops.gr/Ergorama/index.jsp?menuitemId=a1\&tabid=0)

\section{Trends in water supply and demand from industry and agriculture}

Regarding the industry, in the case of the planning of an industrial zone in the area it is likely that the demand for industrial water use will increase considering the need of new land for the establishment of industrial units. As long as agriculture is concerned, during the period 20002006 there has been important investments especially for the reform of the agricultural population through the Operational Program for the "Agricultural Development and Reform of 
the Country Side" which are continued during the period 2007-2013. The population reform of the agricultural sector has as a result the increase of specialized farmers. Combining this effect with the objective of Common Agricultural Policy for a more sustainable agriculture is expected to increase the efficiency of water use and to limit the relevant demand.

In order for the monitoring of the demand to be feasible and to be able to apply measures for its potential limitation, the record and surveillance of all the existent bore holes in both the industrial and agricultural sector.

Regarding industrial water supply it is estimated that it will have a positive trend if the relevant announcements are applied, since the water quality that is provided to the industries will be improved. The agricultural sector does not seem to face a supply problem, since the water balance regarding the Sterea Ellada hydrometric area is positive. The competent bodies for providing water services of the Asopos RB are of particular interest. In the area there are one DEYA, eight Municipalities and one smaller administrative area identified as competent bodies for water provision. However, some of the above bodies provide their services through their collaboration with EYDAP. The way of water provision and treatment as well as the water abstraction points are diversified across the competent bodies and for that reason different quality, quantity and charges of water are observed. Due to the different way of operation of the bodies responsible for water provision (DEYA, Munipalities, and EYDAP) but also to the different financial elements that are included in the calculation of the height of the charge, the result is a highly diverse water policy within Asopos RB. This diversification is not only observed between the different systems of water provision (e.g., between DEYA and 
Municipalities) but it is equally intense within the same system of provision (e.g., across Municipalities).

\section{Conclusions}

This chapter offered an overview of the economic characterization in Asopos RB focusing on the sectors of industry and agriculture. In this context, specific indexes were studied in order to evaluate the economic significance of water use in the industrial and agricultural area of the basin.

According to the study of the Technical Chamber (2009) there are 244 industrial units in the area, which is $6 \%$ of the total industrial units of the country. Therefore, it is observed a considerable concentration of industrial activity in the area, which is in need of a stable water supply. The water that is provided to the industrial units it is used either for the sanitation purposes of the employed or in the production procedure. The employees' needs are not negligible since in the industrial units of the area there 5.507 people. In this number there should be added a considerable number of employees who do not reside within Asopos RB but commute on a daily basis. Regarding employment the most important industrial sectors in the area are the sector of Basic metals and the sector of Other transfer equipment. Other important sectors are those of Foods and Drinks, Products of rubber and plastic material, Metallic products excluding machinery and Products of non metallic minerals. Finally, in the sector of Electric machines and appliances there are 517 people employed who although seem to be only few, they represent the $15 \%$ of the total employment of the sector. The increased industrial activity in the area has considerable needs in raw materials and industrial goods consisting in that way an 
important consumer for other sectors of the economy. This is evident from the fact that in the area it is used the $15,5 \%$ of the consumables.

In order to drive to conclusions regarding the importance of every sector as consumer of raw materials, it is necessary to compare the consumables of the area with the consumables of the whole country, since the raw materials and the industrial goods are not necessary to be produced in the area but to come from any other area of the country or even to be imported from other countries. As a result, the most important sectors are the sectors of Electrical machines and appliances and the sector of the Basic metals while considerable are also the sectors of Foods and Drinks, Other transfer equipment, Products of rubber and plastic materials and of Metallic products excluding machinery.

The industrial sector of the area produces also an important value added, which contributes considerably to the growth of the Greek economy. In particular, in the area it is produced the $11,5 \%$ of the total value added of the corresponding industrial sectors of the country (about 1,2 billion Euros). Comparing the value added per sector with the whole of the country it is observed that the most important sectors are the sectors of the Basic metals and the sector of Electrical machines and appliances. Of considerable importance within the basin is the sector of Foods and Drinks, while in relation to the whole of the country important are the sectors of Other transfer equipment and Products of rubber and plastic materials.

From the above it is concluded that from the sectors that are active in the area, the most important are, compared to the whole country, the sectors of Basic metals, the sector of Electrical 
machines and appliances and the sector of Other transfer equipment (Table 22). Then the sectors of Products of rubber and plastic materials and Metallic products excluding machinery follow, while of less importance is the sector of Foods and Drinks. Especially for the sector of Foods and Drinks it is worth noting that while it seems to be of less importance compared the whole country, it is important compared to the rest of sectors of the area since this sector:

- Occupies the $12 \%$ of employed in the industry of the area

- Consumes the $17 \%$ of the total consumables of the area

- Produces the $22 \%$ of the total value added of the area

Table 22: The importance of industrial sectors of Asopos RB for the whole country

\begin{tabular}{lcccc}
\hline Sector & Employment & Consumables & Value added & Total \\
\hline Basic metals & +++ & +++ & +++ & +++ \\
$\begin{array}{l}\text { Electric machines } \\
\text { and appliances }\end{array}$ & + & +++ & +++ & +++ \\
$\begin{array}{l}\text { Other transfer } \\
\text { equipment }\end{array}$ & +++ & ++ & ++ & +++ \\
$\begin{array}{l}\text { Products of rubber } \\
\text { and plastic }\end{array}$ & ++ & ++ & ++ & ++ \\
materials & & & + & \\
$\begin{array}{l}\text { Metallic products } \\
\text { excluding }\end{array}$ & + & + & & ++ \\
machinery & & & & \\
Foods and drinks & & + & & ++ \\
\hline
\end{tabular}

Regarding the agricultural area within Asopos RB it is estimated that about 300.000 str. are cultivated which correspond to the $1 \%$ of the total cultivated land of the country. The term "relative cultivated land/farmland" defines the total of land in the county in which crops corresponding to these of the study area are cultivated. The most important categories of crops in the area are the hard wheat, the olive trees for olive oil, the cotton, the vineyards and the dry 
onions while compared to the "relative cultivated land" of the whole the country the most important crops are the dry onion (14\% of the country), the non-irrigated cotton ( $9 \%$ of the country), the melons and the vineyards for wine production (about 5,5\% of the country for each of them).

Considering the produced quantities, in the area the total of production is 180 million of kilos and it represents the $1 \%$ of the relative production of the total of the country. The term "relative production" describes the total of the country's production that is produced by crop categories that correspond to these of the study area. The most important crops for the area are the hard wheat, the vineyards, the dry onions, the potatoes and the melons/watermelons while compared to the country's relative production the most important crops area the dry onions $(23 \%$ of the country), the non-irrigated cotton and the vineyards for wine production (6\% of the country for each crop) and the melons (5\% of the country).

From the above it is concluded that the most important crop categories are the hard wheat, the vineyards, the cotton, the olive trees for olive oil production, the dry onions, the potatoes and the melons. Especially the dry onion, the non-irrigated cotton and at a less extent the vineyards for wine production have a considerable contribution to the country's relative production. The importance of these crops can be attributed to the very satisfactory yields that these crops demonstrated in the area compared to the total of the country.

Regarding the irrigation, the average irrigated land during 2004-2006 was about $20 \%$ of the cultivated land. A considerable part of it is covered from the irrigated cotton (about $25 \%$ of the 
irrigated land), which as it has been demonstrated it does not consist an important crop for the area while its contribution to the total of the country is negligible. Another important part of irrigations is related to the vegetables (about 30\%) which seem to be important not only for the area but also for the whole country, while they are also related to the sector of Foods and Drinks, which is also of considerable importance in the area.

It should be also noted that in the area of Asopos RB important subsidies are provided. In 2008 the size of the subsidies reached about $€ 11,5 \mathrm{M}$ distributed to about 4.162 beneficiaries. It is also noted that a considerable number of beneficiaries are not exclusively employed in the agricultural sector. The average number of subsidies reached the $2.800 €$ per person while the maximum amount reached even the $98.309 €$. The subsidies could be related to the resource cost, considering that they may creative incentives for agricultural water use not allowing to be used for other present or future uses. Of course, the decoupling of the direct payments from the production reduces that potential while the perspectives of CAP foresee a support mechanism which is completed decoupled and which will correspond to the support of the income and will have as a prerequisite the compliance with the rules of cross compliance and a series of additional payments which will include among others payment for the environmental public goods which are produced by the agriculture through measures such as fallow land, crop rotation, permanent pastures and plant cover.

Overall, from this chapter it is concluded that both industry and agriculture in the Asopos RB play an important role not only for the area but also for the whole country. In this context, water 
as one of the most important inputs for both sectors consists a considerable factor of the area's economy.

\section{References}

Apostolopoulos, K. 2010. Assessment of the economic importance of water use in the industrial and agricultural areas of Asopos RB. Athens University of Economics and Business, Departement of International and European Studies. Available at: http://www.aueb.gr/users/resees/en/econcharen.html (In Greek)

Commission of the European Communities (CEC) 2000 Directive of the European Parliament and of the Council establishing a framework for Community action in the field of water policy. 1997/0067 (COD), C5-0347/00.

European Communities 2002. Guidance document No. 1, Economics and the environment - the implementation challenge of the Water Framework Directive. A guidance document. Common Implementation Strategy for the Water Framework Directive (2000/60/EC). Brussels: $\quad$ European $\quad$ Commission. Available at http://forum.europa.eu.int/Public/irc/env/wfd/library.

Hellenic Republic. Ministry of Environment Physical Planning and Public Works (MoEPPW),2003. The law for the management of water resources of Greece, Law N.3199/03. Athens, Greece.

Hellenic Republic. Ministry of Environment Physical Planning and Public Works (MoEPPW) 2006. Report on the pressures and qualitative characteristics of water bodies in the water districts of Greece and a methodological approach for further analysis. 
Hellenic Republic. Ministry of Environment Physical Planning and Public Works (MoEPPW)National Technical University of Athens (NTUA), Department of Water Resources and Environmental Engineering, 2008. National Programme for the Management and Protection of Water Resources.

Koundouri, P., Remoundou, K. and Kountouris, Y., 2009. A Note on the Implementation of the Economics of the EU Water Framework Directive under Data Limitations: A rapid appraisal approach. DEOS Working Papers, Athens University of Economics and Business, 2009.

National Statistical Service of Greece, Annual Agricultural Statistical Survey 2004, 2005 and 2006.

Safarikas, N., Paranychianakis, N.V., O. Kotselidou and A.N. Angelakis, 2006. Drinking water policy in the frame of the Directive 2000/60/EC with emphasis on drinking water prices. Water Science and Technology: Water Supply Vol 5 No 6 pp 243-250.

Tsagarakis, K.P., Paranychianakis, N.V. and Angelakis, A.N. (2003). Water Supply and Wastewater Services in Greece. In S. Mohajeri et al. (eds), European Water Management Between Regulation and Competition, Aqualibrium Project, EU-Directorate-General for Research, Global Change and Ecosystems, B-1049, Brussels, Belgium, 151-170.

Technical Chamber of Greece, 2009. The problem of Asopos River-Suggestions for facing it. Report, July 2009. (In Greek) 